\title{
KEPUTUSAN PEMBELIAN BERDASARKAN PERSEPSI, MOTIVASI, DAN SIKAP PADA MARKETPLACE
}

\author{
Pelade Viora \\ peladeviora@gmail.com \\ AMA Suyanto \\ Universitas Telkom \\ J1. Telekomunikasi Terusan Buah Batu, Bandung, Jawa Barat 40257
}

diterima: 2/10/2019; direvisi: 23/12/2020; disetujui: 27/2/2020

\begin{abstract}
The growth of e-commerce in Indonesia raises competition so companies must maintain the existence from total of 49 e-commerce in Indonesia by understanding consumer psychology, namely perception, motivation, and attitude that drive purchasing decision. The purpose of the study to determine consumer response and the influence of perception, motivation, and attitude of consumer toward purchasing decision on marketplace in Indonesia partially or simultaneously. The research method is quantitative with multiple linear regression analysis techniques. The results showed consumer responses to $80.5 \%$ perception, $82 \%$ motivation, and $81.4 \%$ attitude. And there are positive and significant influence partially or simultaneously from the perception, motivation, and attitude towards purchasing decisions on marketplace in Indonesia. Hope this research can be used as a reference for future researchers, specifically using different analytical techniques and business actors in the marketplace to improve services and respond to complaints.
\end{abstract}

Keywords: perception; motivation; attitude; purchasing decision; marketplace

\begin{abstract}
Abstrak
Pertumbuhan e-commerce di Indonesia menimbulkan persaingan sehingga mengharuskan perusahaan mempertahankan eksistensi dari total 49 e-commerce di Indonesia dengan memahami psikologis konsumen yaitu persepsi, motivasi, dan sikap yang mendorong keputusan membeli. Tujuan penelitian untuk mengetahui respon konsumen dan pengaruh persepsi, motivasi, dan sikap konsumen terhadap keputusan pembelian pada marketplace di Indonesia secara parsial maupun simultan. Metode penelitian adalah kuantitatif dengan teknik analisis regresi linear berganda. Hasil penelitian menunjukkan respon konsumen terhadap persepsi $80,5 \%$, motivasi $82 \%$, dan sikap $81,4 \%$. Serta adanya pengaruh positif dan signifikan secara parsial maupun simultan dari persepsi, motivasi, dan sikap terhadap keputusan pembelian pada marketplace di Indonesia. Diharapkan penelitian ini dapat dijadikan referensi bagi peneliti selanjutnya, khususnya menggunakan teknik analisis yang berbeda dan para pelaku usaha di marketplace meningkatkan layanan dan respon terhadap keluhan.
\end{abstract}

Kata Kunci: persepsi; motivasi; sikap; keputusan pembelian; marketplace 


\section{PENDAHULUAN}

Pertumbuhan belanja online di Indonesia merupakan yang tercepat di Asia Tenggara. Oleh karena itu, Indonesia dikatakan pasar belanja online paling potensial (Tresnady \& Krisnamusi, 2017). Belanja online lebih menguntungkan karena promo dan diskon yang diberikan e-commerce lebih menarik dibanding offline. Kondisi ini membuat shopaholic perlahan menggandrungi belanja online (Nur, 2017). Pembelian produk via e-commerce Indonesia mencapai Rp 146,7 triliun, meningkat $41 \%$ dari Rp 74 triliun pada 2015 (Iskandar, 2018). Pertumbuhan belanja online dikarenakan peningkatan industri e-commerce selama sepuluh tahun terakhir sebesar $17 \%$ dan total jumlah usaha e-commerce mencapai 26,2 juta unit (Rahayu, 2019). Para pelaku bisnis mulai bersaing, khususnya marketplace sebagai media jual beli bagi pelaku bisnis lainnya. Marketplace berusaha mendapatkan pangsa pasar yang lebih besar dari pesaing. Oleh karena itu, marketplace harus mempertimbangkan yang menjadi dasar keputusan pembelian konsumen.

Berdasarkan laporan survei iPrice 2017, aplikasi marketplace yang paling popular adalah Shopee (Haryanto, 2017). Sementara Lazada memiliki pengunjung website marketplace paling banyak pada 2017 (iPrice, 2018). Akan tetapi, survei yang dilakukan FTCR menunjukkan Tokopedia memiliki pengunjung website marketplace paling banyak daerah urban (Savithri, 2018). Selain itu, pertengahan 2018 Tokopedia berhasil menempati posisi pertama pengunjung website marketplace versi iPrice 2018. Hal ini menunjukkan adanya perbedaan eksistensi pada marketplace. Peningkatan persaingan antara pelaku bisnis menuntut perusahaan untuk mempertahankan pasar. Pemasaran dalam mengukur keberhasilan diperlukan kemampuan untuk mempertahankan produk dan meningkatkan pangsa pasar (Kotler, 2006). Pada konteks ini yang menjadi sorotan adalah mempertahankan visitor share pada marketplace. Tingkat penjualan yang tinggi merupakan tujuan yang diinginkan oleh marketplace, karena perusahan akan dinilai semakin baik apabila penjualan semakin meningkat. Meningkatkan traffic pengunjung website dapat memberi peluang atau kesempatan yang lebih besar untuk meningkatkan pendapatan (Commetagroup, 2017). Oleh karena itu, penting bagi marketplace untuk memperhatikan hal yang menjadi dasar keputusan pembelian konsumen untuk mempertahankan pasar. Salah satu faktor yang mempengaruhi keputusan pembelian adalah faktor psikologis. Faktor psikologis merupakan faktor yang dapat mendorong stimuli pemasaran. Keputusan pembelian konsumen didorong oleh kebutuhan fungsional puas dengan fungsi produk dan kebutuhan emosional yang terkait dengan aspek psikologis kepemilikan produk (Consoli, 2009). Aspek psikologis tersebut yaitu persepsi, motivasi, dan sikap yang mempengaruhi respon konsumen terhadap stimuli pemasaran. Penelitian lain juga menyebutkan responden setuju bahwa faktor psikologis dapat mempengaruhi konsumen dalam berbelanja (Yolanda \& Herwinda, 2017).

Perilaku konsumen adalah perilaku yang diperlihatkan konsumen dalam proses mencari, membeli, menggunakan, mengevaluasi, dan menghabiskan produk yang dapat memuaskan kebutuhan konsumen (Priansa, 2017). Perilaku konsumen dipengaruhi oleh beberapa faktor. Adapun faktor tersebut yaitu faktor budaya, sosial, pribadi, dan psikologis. Persepsi adalah proses individu dalam memilih, mengatur, dan menerjemahkan informasi yang ditangkap untuk menciptakan gambaran dunia yang berarti (Mawey, 2013). Pemasar menggunakan persepsi konsumen untuk merumuskan strategi pemasaran. Pemasar akan menggunakan peta persepsi konsumen agar mereka mengetahui atribut atau karakteristik konsumen dikaitkan dengan produk, sehingga pemasar bisa membuat produk yang sesuai (Diyarbakirlioglu \& Durmaz, 2011). Persepsi sering kali mendorong pembelian karena merupakan interpretasi informasi sensorik (Lindberg et. al., 2018). Motivasi merupakan sekumpulan proses psikologis yang mengakibatkan pergerakan, arahan, dan kegigihan dari sikap sukarela yang mengarah kepada tujuan (Mawey, 2013). Sikap adalah pernyataan atau penilaian evaluatif yang berkaitan dengan objek, orang, atau peristiwa (Wahyuni, 2008). Faktor psikologis mengacu pada karakterisitik kognitif yang mengacu pada sikap dan perilaku konsumen. Faktor ini dapat mempengaruhi cara berfikir konsumen yang akan mempengaruhi keputusannya (Sanad, 2016). Keputusan pembelian adalah proses integrasi yang mengkombinasikan pengetahuan untuk mengevaluasi dua atau lebih perilaku alternatif, dan memilih salah satu diantaranya (Sangadji \& Sopiah, 2013).

Perbedaan eksistensi yang terjadi pada marketplace dikarenakan stimuli yang disampaikan oleh marketplace dan stimuli yang diterima konsumen berbeda-beda. Perbedaan ini berdampak pada visitor share marketplace. Oleh sebab itu, marketplace harus memperhatikan stimuli pemasaran agar tetap menjadi pilihan konsumen untuk membeli. Kotler dan Amstrong menyebutkan salah satu faktor yang mempengaruhi keputusan pembelian yaitu faktor psikologis. Faktor psikologis merupakan faktor yang dapat mendorong stimuli pemasaran, diantaranya yaitu persepsi, motivasi, dan sikap. Hal ini juga didukung oleh penelitian terdahulu yang menyataan bahwa persepsi, motivasi, dan sikap berpengaruh positif dan signifikan terhadap keputusan pembelian pada masing-masing objek penelitian, Mawey (2013), Tompunu (2014), Saputra (2013), Mauliansyah (2015), Sepang \& Joel (2014). Sehingga hipotesis pada penelitian ini adalah sebagai berikut: (1) Persepsi berpengaruh positif dan signifikan terhadap keputusan pembelian pada marketplace di Indonesia; (2) Motivasi berpengaruh positif dan signifikan terhadap 
keputusan pembelian pada marketplace di Indonesia; (3) Sikap berpengaruh positif dan signifikan terhadap keputusan pembelian pada marketplace di Indonesia; (4) Persepsi, motivasi, dan sikap berpengaruhi positif dan signifikan secara simultan terhadap keputusan pembelian pada marketplace di Indonesia.

Berdasarkan tinjuan teori yang telah dikembangkan maka kerangka konseptual pada penelitian ini dapat dilihat pada Gambar 1.

\section{METODE}

Metode penelitian yang digunakan adalah kuantitatif dengan menggunakan teknik analisis regresi linear berganda. Tujuan penelitian adalah deskriptif dan kausal. Populasi dalam penelitian ini adalah masyarakat Indonesia yang melakukan pembelian pada marketplace di Indonesia. Jumlah populasi penelitian tidak diketahui dengan pasti, maka pengukuran sampel menggunakan rumus Bernoulli sehingga didapat sampel sebanyak 385 orang. Teknik pengambilan sampel yang digunakan adalah non-probability sampling. Jenis kriteria sampel yang digunakan adalah purposive sampling. Teknik pengumpulan data dilakukan dengan menyebarkan kuesioner kepada responden dan studi pustaka. Skala pengukuran yang digunakan adalah skala likert. Operasionalisasi variabel ditunjukkan pada Tabel 1.

\section{HASIL}

Karakteristik responden yang digunakan yaitu jenis kelamin, usia, domisili, pekerjaan, frekuensi belanja per bulan pada marketplace, pengeluaran per bulan pada marketplace. Hasil pengolahan data dengan responden sebanyak 385 orang didapatkan karakteristik responden didominasi oleh jenis kelamin perempuan sebesar 59,7\%, usia 20-36 tahun sebesar $79,7 \%$, domisili Indonesia bagian Barat sebesar 90,9\%, pekerjaan mahasiswa sebesar $78,4 \%$, frekuensi belanja per bulan kurang dari 3 kali sebesar $77,7 \%$, pengeluaran per bulan Rp 100.000 - Rp 500.000 sebesar 63,1\%. Berdasarkan hasil perhitungan dengan Microsoft Exel, didapatkan total skor persepsi sebesar $80,5 \%$, skor motivasi sebesar $82 \%$, dan skor sikap sebesar $81,4 \%$.

Analisis deskriptif menunjukkan respon konsumen terhadap persepsi pada marketplace adalah $80,5 \%$ berada pada kategori tinggi, dapat dilihat pada Gambar 2. Berikutnya respon konsumen terhadap motivasi pada marketplace adalah $82 \%$ berada pada kategori tinggi, dapat dilihat pada Gambar 3. Berikutnya respon konsumen terhadap sikap pada marketplace adalah $81,4 \%$ berada pada kategori tinggi, dapat dilihat pada Gambar 4.

Berdasarkan uji asumsi klasik, menunjukkan bahwa data berdistribusi normal, tidak terjadi multikolinearitas antara variabel bebas, dan tidak terjadi heteroskedastisitas.
Berdasarkan pengujian regresi linear berganda, didapat nilai konstanta dan koefisien regresi sebagai berikut:

$\mathrm{Y}=378,813+0,386\left(\mathrm{X}_{1}\right)+0,426\left(\mathrm{X}_{2}\right)+0,285\left(\mathrm{X}_{3}\right) \ldots \ldots .(1)$

Berdasarkan uji t pada Tabel 2 yang dilakukan diperoleh nilai t hitung $X_{1}=5,960 ; X_{2}=5,494 ; X_{3}=3,976$ dimana semua nilai lebih besar dari $t$ tabel 1.966 dan semua nilai signifikan 0 lebih besar dari 0,05 , dimana H0 ditolak. Sementara uji F pada Tabel 3 didapat nilai F hitung 134,677 lebih besar dari nilai $F$ tabel 2,628 dan nilai signifikan 0 lebih besar dari 0,05 , dimana $\mathrm{H} 0$ ditolak.

Berdasarkan pengujian koefisien determinasi pada Tabel 4 didapat nilai $R$ Square 0,515 yang menunjukkan bahwa persepsi, motivasi, dan sikap memberikan pengaruh 51,5\% terhadap keputusan pembelian. Sisanya 48,5\% merupakan kontribusi variabel selain persepsi, motivasi, dan sikap.

\section{PEMBAHASAN}

Uji validitas pada pernyataan kuesioner menunjukkan hasil valid dan reliabel. Pengujian hipotesis secara parsial dilakukan dengan membandingkan t hitung dengan $t$ tabel. Jika nilai t hitung yang didapatkan lebih besar dari nilai $t$ tabel, maka H0 ditolak atau terdapat pengaruh signifikan. Variabel persepsi memiliki nilai t hitung 5,960 lebih besar dari nilai t tabel 1,966, maka H0 ditolak. Oleh karena itu, dapat dikatakan bahwa persepsi terdapat pengaruh yang signifikan terhadap keputusan pembelian pada marketplace di Indonesia. Koefisien regresi variabel persepsi memiliki nilai positif. Hal ini menunjukkan bahwa variabel persepsi memiliki hubungan searah dengan keputusan pembelian (Y). Apabila persepsi pelanggan tinggi, maka akan meningkatkan keputusan pembelian pada marketplace.

Berikutnya, variabel motivasi memiliki nilai thitung 5,494 lebih besar dari nilai t tabel 1,966, maka H0 ditolak. Oleh karena itu, dapat dikatakan bahwa motivasi terdapat pengaruh signifikan terhadap keputusan pembelian pada marketplace di Indonesia. Koefisien regresi variabel motivasi memiliki nilai positif. Hal ini menunjukkan bahwa variabel motivasi memiliki hubungan searah dengan keputusan pembelian Apabila motivasi pelanggan tinggi, maka akan meningkatkan keputusan pembelian pada marketplace.

Sementara variabel sikap $\left(\mathrm{X}_{3}\right)$, memiliki nilai $\mathrm{t}$ hitung 3,976 lebih besar dari nilai $t$ tabel 1,966, maka H0 ditolak. Oleh karena itu, dapat dikatakan bahwa sikap terdapat pengaruh signifikan terhadap keputusan pembelian pada marketplace di Indonesia. Koefisien regresi variabel sikap memiliki nilai positif. Hal ini menunjukkan bahwa variabel sikap memiliki hubungan searah dengan keputusan pembelian. Apabila sikap pelanggan tinggi, maka akan meningkatkan keputusan pembelian pada marketplace. 
Pengujian hipotesis secara simultan dilakukan dengan membandingkan $\mathrm{f}$ hitung dengan $\mathrm{f}$ tabel. Hasil yang didapatkan adalah nilai $\mathrm{f}$ hitung 134,677 lebih besar dari nilai f tabel 2,628, maka H0 ditolak. Oleh karena itu dapat dikatakan bahwa persepsi, motivasi, dan sikap secara positif berpengaruh signifikan terhadap keputusan pembelian secara simultan atau bersamasama.

Jika dibandingkan dengan penelitian terdahulu hasil analisis hipotesis penelitian ini sama dengan hasil analisis hipotesis penelitian terdahulu yaitu persepsi, motivasi, dan sikap berpengaruh positif dan signifikan terhadap keputusan pembelian secara parsial dan simultan (Mawey, 2013). Penelitian lain juga menyebutkan persepsi, motivasi, dan sikap berpengaruh positif dan signifikan terhadap keputusan pembelian secara parsial dan simultan (Saputra \& Semuel, 2013). Penelitian lainnya juga mengatakan persepsi, motivasi, dan sikap berpengaruh positif dan signifikan terhadap keputusan pembelian secara parsial dan simultan (Tompunu, 2014). Hanya saja penelitian ini menambahkan variabel pembelajaran. Penelitian lainnya yang menambahkan variabel berbeda seperti motivasi, persepsi harga, dan kualitas produk berpengaruh positif dan signifikan secara parsial dan simultan terhadap minat beli (Sepang \& Joel, 2014) dan penelitian motivasi, persepsi kualitas, dan sikap berpengaruh secara positif dan signifikan secara parsial dan simultan terhadap keputusan pembelian (Mauliansyah, 2015).

Sementara penelitian lain menyebutkan bahwa motivasi perilaku belanja online tidak bergantung pada usia responden (Svatosova, 2013). Penelitian lainnya menyebutkan bahwa penggunaan media WOM memiliki dampak positif pada keterlibatan keputusan pembelian dan kepercayaan online memainan peran mediasi penting pada kontek ini (Prasad, et. al., 2017). Penelitian lainnya menyebutkan bahwa sikap konsumen terhadap strategi promosi pengecer mal dipengaruhi oleh nilai belanja dan kesadaran harga, kecendrungan membeli, dan membagikan kupon (Khare et al., 2014). Berbeda dengan penelitian yang menyebutkan bahwa kualitas produk parsial memiliki pengaruh signifikan terhadap keputusan pembelian, tetapi variabel psikologis tidak mempengaruhi keputusan pembelian konsumen. Variabel Psikologi Konsumen memoderasi hubungan antara factor keputusan pembelian (Yulianda \& Handayani, 2015).

\section{KESIMPULAN}

Berdasarkan hasil penelitian terhadap 385 responden yang telah dilakukan, penulis mendapatkan beberapa kesimpulan. Adapun uraian kesimpulan penelitian ini adalah sebagai berikut: (1) Respon konsumen terhadap persepsi yaitu sebesar $80,5 \%$, motivasi yaitu $82 \%$, dan sikap yaitu $81,4 \%$, masing-masing menempati posisi yang tinggi pada garis kontinum tanggapan responden; (2) Persepsi memiliki pengaruh positif dan signifikan terhadap keputusan pembelian pada marketplace di Indonesia; (3) Motivasi memiliki pengaruh positif dan signifikan terhadap keputusan pembelian pada marketplace di Indonesia; (4) Sikap memiliki pengaruh positif dan signifikan terhadap keputusan pembelian pada marketplace di Indonesia; (5) Persepsi, motivasi, dan sikap memiliki pengaruh positif dan signifikan secara bersama-sama terhadap keputusan pembelian pada marketplace di Indonesia.

\section{DAFTAR PUSTAKA}

Commetagroup. 2017. Meningkatkan Traffic Pengunjung Toko Online Dengan 3 Langkah Mudahc. Diambil dari commeta.co.id: http:// commeta.co.id/meningkatkan-traffic-pengunjungtoko-online-dengan-3-langkah-mudah/

Consoli, D. 2009. Emotions That Influence Purchase Decisions And Their Electronic Processing. Annales Universitatis Apulensis Series Oeconomica, 2(11), $1-45$.

Diyarbakirlioglu, I., \& Durmaz, Y. 2011. A Theoritical Approach To the Role of Perception on the Consumer. Asian Journal of Business and Management Sciences, 1(4), 217-221.

Haryanto, R. 2017. Persaingan e-Commerce Indonesia di 2017, Siapa Terpopuler? Diambil dari detikinet: https://inet.detik.com/cyberlife/d-3793019/ persaingan-e-commerce-indonesia-di-2017-siapaterpopuler

Indrawati. 2015. Metode Penelitian Manajemen dan Bisnis. Bandung: Refika Aditama.

iPrice. 2018. Peta E Commerce Indonesia. Diambil dari IPrice Group: https://iprice.co.id/insights/ mapofecommerce/

iPrice Group. 2017. State of eCommerce Asia Tenggara 2017. Diambil dari iprice.co.id: https://iprice.co.id/ insights/stateofecommerce2017/

Iskandar. 2018. Orang Indonesia Habiskan Rp 146 Triliun untuk Belanja Online. Diambil dari Liputan6.com: https://www.liputan6.com/tekno/ read/3326217/orang-indonesia-habiskan-rp-146triliun-untuk-belanja-online?related=dable\&utm expid=.9Z4i5ypGQeGiS7w9arwTvQ.1\&utm referrer $=$ https $\% 3 \mathrm{~A} \% 2 \mathrm{~F} \% 2 \mathrm{Fwww}$.google.com $\% 2 \overline{\mathrm{F}}$

Khare, A., Achtani, D., \& Khattar, M. 2014. Influence of price perception and shopping motives on Indian consumers' attitude towards retailer promotions in malls. Asia Pacific Journal of Marketing and Logistics, 26(2), 272-295.

Kotler, P. 2006. Manajemen Pemasaran. Jakarta: PT. Indeks Kelompok Gramedia.

Lindberg, U., Salomonson, N., Sundström, M., \& Wendin, K. 2018. Consumer perception and behavior in the retail foodscape-A study of chilled 
groceries. Journal of Retailing and Consumer Services, 40(August 2017), 1-7. https://doi. org/10.1016/j.jretconser.2017.09.001

Mauliansyah, R. 2015. Analisis Pengaruh Motivasi, Persepsi Kualitas dan Sikap Konsumen terhadap Keputusan Pembelian Sepeda Motor Honda di Kota Langsa. Jurnal Manajemen Dan Keuangan Unsam, 4(1), 317-328.

Mawey, H. E. 2013. Motivasi, Persepsi, Dan Sikap Konsumen Pengaruhnya Terhadap Keputusan Pembelian Produk Pt. Rajawali Nusindo Cabang Manado. Jurnal Riset Ekonomi, Manajemen, Bisnis Dan Akuntansi, 1(4), 791-801.

Nur, M. 2017. Kata Survei, Ini Alasan Shopaholic Lebih Menyukai Belanja Online. Diambil dari Jawapos.com: https://www.jawapos.com/ ekonomi/bisnis/13/12/2017/kata-survei-ini-alasanshopaholic-lebih-menyukai-belanja-online

Prasad, S., Gupta, I. C., \& Totala, N. K. 2017. Social media usage, electronic word of mouth and purchase-decision involvement. In Asia-Pacific Journal of Business Administration (Vol. 9, Issue 2). https://doi.org/10.1108/APJBA-06-2016-0063

Priansa, D. J. 2017. Perilaku Konsumen dalam Persaingan Bisnis Kontemporer. Bandung: Alfabeta.

Rahayu, N. 2019. Pertumbuhan E-Commerce Pesat di Indonesia. Diambil dari Werta Ekonomi: https://www.wartaekonomi.co.id/read216302/ pertumbuhan-e-commerce-pesat-di-indonesia.html

Sanad, R. A. 2016. Consumer Attitude and Purchase Decision towards Textiles and Apparel Products. World Journal of Textile Engineering and Technology, 2, 16-30.

Sangadji, E. M., \& Sopiah. 2013. Perilaku Konsumen. Yogyakarta: C. V. Andi Offset.

Saputra, R., \& Semuel, H. 2013. Analisa Pengaruh Motivasi, Persepsi, Sikap Konsumen Terhadap Keputusan Pembelian Mobil Daihatsu Xenia di Sidoarjo. Jurnal Manajemen Pemasaran, 1(1), 1-12.
Savithri, A. 2018. Sektor E-commerce Tumbuh, Tokopedia Merajai Pasar Indonesia. Diambil dari cnnindonesia: https://www.cnnindonesia.com/ teknologi/20180221105010-185-277674/sektore-commerce-tumbuh-tokopedia-merajai-pasarindonesia.

Sepang, J., \& Joel, G. 2014. Pengaruh Motivasi, Persepsi Harga, Dan Kualitas Produk Terhadap Minat Beli Konsumen Sepeda Motor Matic Merek Yamaha Mio Di Kota Manado. Jurnal Riset Ekonomi, Manajemen, Bisnis Dan Akuntansi, 2(3), 14631472.

Svatosova, V. 2013. Motivation of Online Buyer Behavior. Journal of Competitiveness, 5(3), 14-30. https://doi.org/10.7441/joc.2013.03.02

Tompunu, M. M. 2014. Analisis Motivasi, Persepsi, Pembelajaran, Dan Sikap Konsumen Pengaruhnya Terhadap Keputusan Pembelian Di Kfc Bahu Mall Manado. Jurnal Riset Ekonomi, Manajemen, Bisnis Dan Akuntansi, 2(3), 610-621.

Tresnady, T., \& Krisnamusi, I. A. 2017. Separuh Generasi Millennial Indonesia Rutin Belanja Online. Diambil dari Suara.com: https://www.suara. com/tekno/2017/03/15/190906/separuh-generasimillennial-indonesia-rutin-belanja-online

Wahyuni, D. U. 2008. Pengaruh Motivasi, Persepsi, dan Sikap Konsumen terhadap Keputusan Pembelian Sepeda Motor Mrek Honda di Kawasan Surabaya Barat. Ekonomi Manajemen, 30.

Yolanda, A., \& Herwinda, V. 2017. Affect Of Cultural Factor On Consumer Behaviour In Online Shop. International Journal of Scientific \& Technology Research, 6(6), 287-292.

Yulianda, S., \& Handayani, T. 2015. The Effect of Two Aspects-Quality Products and Consumers Psychology - Toward the Purchase Decisions of Samsung Mobile Phone. Mediterranean Journal of Social Sciences, 6(5), 203-208. https://doi. org/10.5901/mjss.2015.v6n5s5p203 
Tabel 1. Operasionaliasi Variabel

\begin{tabular}{|c|c|c|c|}
\hline Variabel & $\begin{array}{l}\text { Definisi Operasional dan } \\
\text { Referensi }\end{array}$ & Indikator & Pernyataan pada penelitian ini \\
\hline \multirow[t]{4}{*}{$\begin{array}{l}\text { Persepsi } \\
\left(\mathrm{X}_{1}\right)\end{array}$} & \multirow{3}{*}{$\begin{array}{l}\text { Proses individu dalam } \\
\text { memilih, mengatur, dan } \\
\text { menerjemahkan informasi } \\
\text { yang ditangkap untuk } \\
\text { menciptakan gambaran } \\
\text { dunia yang berarti. }\end{array}$} & Kemudahan penggunaan & $\begin{array}{l}\text { Mudah dalam pemesanan barang, transaksi, dan komunikasi } \\
\text { dengan marketplace. }\end{array}$ \\
\hline & & $\begin{array}{l}\text { Karakteristik tambahan } \\
\text { yang menjadi pembeda }\end{array}$ & $\begin{array}{l}\text { Marketplace memilki fitur unik sebagai pembeda (seperti live } \\
\text { chatt, cash on delivery). }\end{array}$ \\
\hline & & Kehandalan barang & $\begin{array}{l}\text { Marketplace memiliki layanan dan respon yang cepat terhadap } \\
\text { keluhan. }\end{array}$ \\
\hline & $\begin{array}{l}\text { Philip Kotler dan Kevin } \\
\text { Lane Keller (2012) }\end{array}$ & $\begin{array}{l}\text { Popularitas merek } \\
\text { produk }\end{array}$ & $\begin{array}{l}\text { Promo, iklan, event, dan citra merek dari marketplace sudah } \\
\text { familiar. }\end{array}$ \\
\hline \multirow{4}{*}{$\begin{array}{l}\text { Motivasi } \\
\left(\mathrm{X}_{2}\right)\end{array}$} & \multirow{3}{*}{$\begin{array}{l}\text { Kekuatan dorongan dari } \\
\text { dalam diri yang memaksa } \\
\text { individu untuk melakukan } \\
\text { suatu tindakan. }\end{array}$} & Harga produk & Harga produk yang ditawarkan oleh marketplace lebih murah. \\
\hline & & Kualitas produk & $\begin{array}{l}\text { Kualitas produk yang dijual baik dan sesuai dengan harga yang } \\
\text { ditawarkan oleh marketplace. }\end{array}$ \\
\hline & & Ketersediaan barang & Produk yang dipesan memiliki ketersediaan barang (ready stock). \\
\hline & Schiffman dan Kanuk (2010) & $\begin{array}{l}\text { Tren terhadap produk di } \\
\text { lingkungan sosial }\end{array}$ & $\begin{array}{l}\text { Marketplace membuat promo mengikuti tren saat ini (seperti } \\
\text { flash sale, cash back, voucher, gratis ongkos kirim). }\end{array}$ \\
\hline \multirow[t]{4}{*}{ Sikap $\left(\mathrm{X}_{3}\right)$} & \multirow{3}{*}{$\begin{array}{l}\text { Sikap adalah pernyataan } \\
\text { atau penilaian evaluatif yang } \\
\text { berkaitan dengan objek, } \\
\text { orang, atau peristiwa. }\end{array}$} & Merek produk & Marketplace memiliki logo dan nama yang mudah diingat. \\
\hline & & $\begin{array}{l}\text { Pengetahuan terhadap } \\
\text { produk }\end{array}$ & Pembelian produk pada marketplace dapat dipercaya. \\
\hline & & $\begin{array}{l}\text { Perasaan seseorang } \\
\text { terhadap produk }\end{array}$ & Marketplace memiliki layanan yang baik. \\
\hline & Setiadi (2008) & Kehandalan produk & Marketplace dapat menghemat pengeluaran dan waktu. \\
\hline \multirow{6}{*}{$\begin{array}{l}\text { Keputusan } \\
\text { Pembelian } \\
\text { (Y) }\end{array}$} & \multirow{4}{*}{$\begin{array}{l}\text { Keputusan Pembelian adalah } \\
\text { proses pengintegrasian } \\
\text { yang mengkombinasikan } \\
\text { pengetahuan untuk } \\
\text { mengevaluasi dua atau } \\
\text { lebih perilaku alternatif, } \\
\text { dan memilih salah satu } \\
\text { diantaranya. }\end{array}$} & $\begin{array}{l}\text { Tidak ada pemilihan } \\
\text { merek lain }\end{array}$ & Produk yang diinginkan hanya tersedia pada marketplace. \\
\hline & & $\begin{array}{l}\text { Informasi tentang } \\
\text { kualitas }\end{array}$ & $\begin{array}{l}\text { Marketplace hanya menjual produk yang berkualitas baik dan } \\
\text { tidak rusak. }\end{array}$ \\
\hline & & $\begin{array}{l}\text { Ketertarikan untuk } \\
\text { membeli ulang }\end{array}$ & $\begin{array}{l}\text { Merasa puas dan ingin melakukan pembelian ulang pada } \\
\text { marketplace. }\end{array}$ \\
\hline & & $\begin{array}{l}\text { Pengenalan terhadap } \\
\text { masalah }\end{array}$ & Melakukan pembelian pada matketplace karena kebutuhan. \\
\hline & \multirow[t]{2}{*}{ Peter dan Olson (2000) } & & Melakukan pembelian pada marketplace karena keinginan. \\
\hline & & & Melakukan pembelian pada marketplace karena pengaruh promo. \\
\hline
\end{tabular}

Tabel 2. Analisis Regresi Linear Berganda

\begin{tabular}{|c|c|c|c|c|c|}
\hline \multirow{2}{*}{ Model } & \multicolumn{2}{|c|}{$\begin{array}{l}\text { Unstandardized } \\
\text { Coefficients }\end{array}$} & \multirow{2}{*}{$\begin{array}{c}\text { Standardized } \\
\text { Coefficients }\end{array}$} & \multirow{2}{*}{$\mathrm{t}$} & \multirow{2}{*}{ Sig. } \\
\hline & B & Std. Error & & & \\
\hline (Constant) & 378.813 & 85.824 & & 4.414 & .000 \\
\hline Persepsi & .386 & .065 & .292 & 5.960 & .000 \\
\hline Motivasi & .426 & .078 & .307 & 5.494 & .000 \\
\hline Sikap & .285 & .072 & .214 & 3.976 & .000 \\
\hline
\end{tabular}

Tabel 3. Uji F

\begin{tabular}{lccccc}
\multicolumn{6}{c}{ ANOVA $^{\mathrm{a}}$} \\
\hline \multicolumn{1}{c}{ Model } & Sum of Squares & df & Mean Square & F & Sig. \\
\hline Regression & 27004738.763 & 3 & 9001579.588 & 134.677 & $.000^{\mathrm{b}}$ \\
Residual & 25465298.977 & 381 & 66838.055 & & \\
Total & 52470037.740 & 384 & & & \\
\hline
\end{tabular}

Tabel 4. Koefisien Determinasi

Model Summary

\begin{tabular}{ccccc}
\hline Model & $\mathrm{R}$ & $\begin{array}{c}\mathrm{R} \\
\text { Square }\end{array}$ & $\begin{array}{c}\text { Adjusted } \\
\text { R Square }\end{array}$ & $\begin{array}{c}\text { Std. Error of } \\
\text { the Estimate }\end{array}$ \\
\hline & $.717^{\mathrm{a}}$ & .515 & .511 & 258.53057 \\
\hline
\end{tabular}




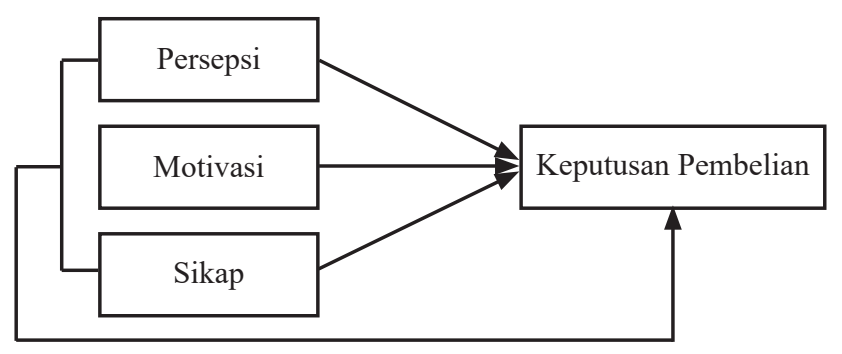

Gambar 1. Kerangka Pemikiran

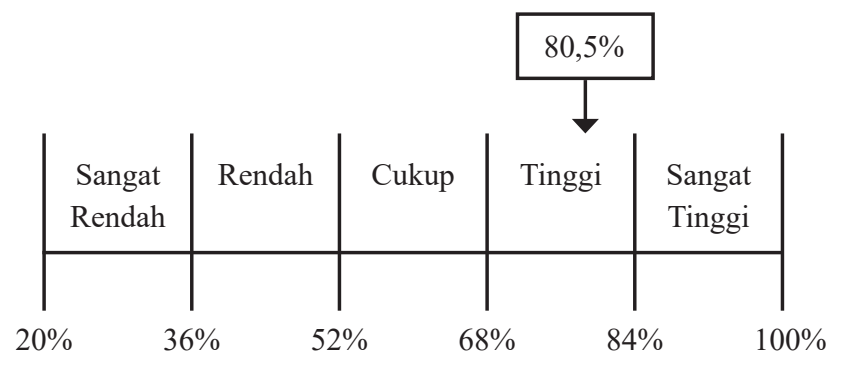

Gambar 2. Garis Kontinum Persepsi

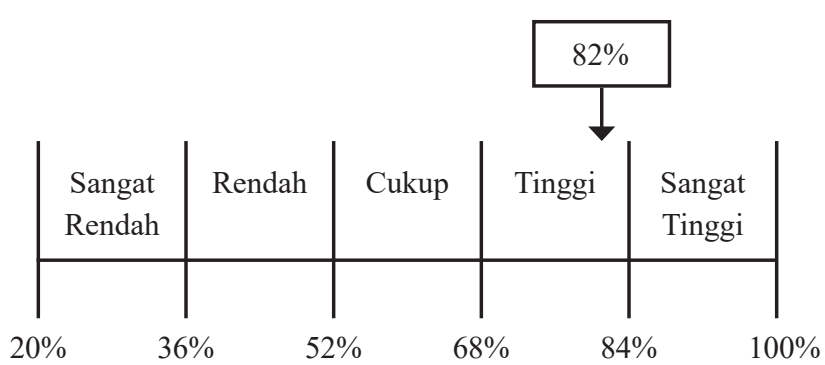

Gambar 3. Garis Kontinum Motivasi

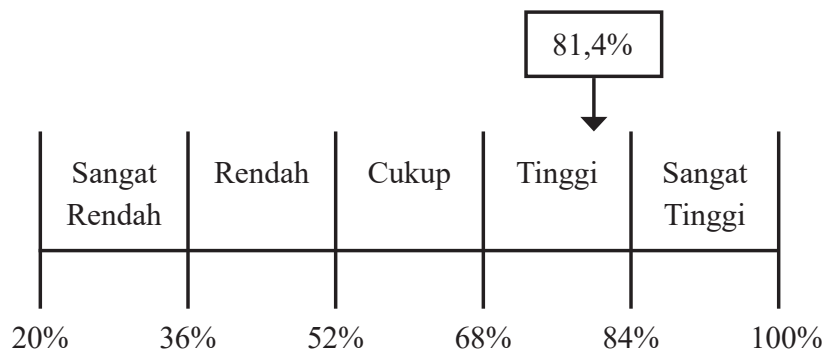

Gambar 4. Garis Kontinum Sikap 